\title{
Has the Euro Promoted Eurozone's Growth?
}

Petros E. Ioannatos

Kettering University, Michigan, United States

\begin{abstract}
This study aims to assess whether the introduction of the euro promotes systematic growth for the Eurozone. The empirical analysis is based on a natural experiment where the difference-in-differences method is applied to compare Eurozone's growth rate with that of selected non-Eurozone economies. The major finding of the study is that there are no significant growth effects for the Eurozone emerging from the introduction of the euro.
\end{abstract}

JEL Classifications: F15, F36, F43, F45, C54

Keywords: Currency Union, Euro, Economic and Monetary Union, Eurozone, Euro Area, European Union, Neoclassical Growth Model, Policy Evaluation, Natural Quasi Experiment, Difference-in-Differences.

\footnotetext{
* Corresponding Author: Petros E. Ioannatos; Kettering University, College of Sciences and Liberal Arts, Department of Liberal Studies, 1700 University Avenue, Flint, Michigan 48504, U.S.A. Tel: +(810) 762-7955, Fax: +(810) 762-9857, Email: pioannat@kettering. edu.
} 


\section{Introduction}

The formation of the Economic and Monetary Union (EMU), also known as Eurozone, was a step towards tightening the integration process of the European Union (EU). The Eurozone was formed in 1999 when most EU member countries pegged their respective nominal exchange rates to a single currency, the euro. It was the moment of creation for the world's largest single currency area. Subsequently, Eurozone member countries abandoned their own monetary policies in favor of a common monetary policy based on the euro, which was implemented by the European Central Bank. In addition, Eurozone member countries are required to coordinate their fiscal policies according to the Stability and Growth Pact, which imposes limits on government borrowing and national debt.

Despite the initial enthusiasm about the prospects of the single currency to promote the prosperity of the Eurozone, the enormous Eurozone undertaking has caused ample skepticism as the introduction of the euro was followed by an unprecedented Eurozone crisis. Some members of the Eurozone, such as Italy, Spain, Portugal, Ireland, and Cyprus, had to implement unpopular austerity measures, while other members, such as Greece, were faced with a sovereign debt crisis. It is evident that the single currency has caused adverse economic effects for several Eurozone members. Naturally, these effects threatened not only the economic stability of the affected members but also Eurozone's existence itself.

In view of the skepticism toward the euro, this study aims to examine whether the euro has promoted the growth rate of the Eurozone. In particular, this study attempts to determine whether a causal effect exists between the euro and the growth rate of the Eurozone, and thus, whether there are systematic growth effects for the Eurozone associated with the euro. The empirical analysis employed a natural experiment, using the Difference-inDifferences (DiD) method, to compare the growth rate of the Eurozone with that of several non-Eurozone economies which exhibit similar characteristics 
with the Eurozone. The euro will turn out to be a success if the Eurozone's growth surpasses that of the non-Eurozone economies.

\section{Literature Review}

The introduction of the euro has sparked considerable academic interest on how such a currency union has affected the Eurozone and the global economy. Rose (2000, 2001) and Glick and Rose (2002) suggested that the formation of the Eurozone has a substantial impact on trade. Subsequently, Bun and Klaasen (2007) and Berger and Nitsch (2008) showed that the impact of the euro on trade has not been as substantial, as initially thought. Nitsch and Pisu (2008) presented evidence that the impact of the euro on trade has been largely overestimated. In addition, Sousa (2012) demonstrated that the impact of the currency union on trade, even though positive, is decreasing over time. Kunroo et al. (2016) showed that the euro can cause economic convergence among Eurozone countries through intra-industry trade. The euro has also affected foreign direct investment (FDI). Petroulas (2007), Schiavo (2007), Brouwer et al. (2008), and Baldwin et al. (2008) suggested that the euro had a profound impact on intra-Eurozone FDI flows as well as FDI flows to and from the Eurozone to third countries. Abbott and De Vita (2011) further illustrated this view.

Previous studies have focused on the advantages of a single currency over national currencies. Vickers (2000) indicated the advantages of eliminating the nominal exchange rate movement, as well as the importance of supplyside factors for economic growth. Mundell $(2000,2003)$ supported that a global currency is needed for global growth and that the euro is a step toward the right direction. Wyplosz (2006) demonstrated that despite some secondary difficulties, the euro has been a major success. Lane (2006) argued that the elimination of exchange rate uncertainty would lead to real convergence between members, and in turn, higher levels of output and growth. Barrell et 
al. (2008) showed that the euro affected output growth directly, reduced real exchange rate volatility, and influenced the accumulation of production capital. Subsequent studies have demonstrated that the Eurozone has encountered difficulties but the trend about the euro has continued to be optimistic. Wickens (2010) discussed some of the unpleasant consequences for joining in the euro, whereas Teulon (2011) raised concerns regarding debt sustainability in the Eurozone and discussed several related proposals. Furthermore, Flassbeck and Friederike (2011) pointed to several misunderstandings about the euro that need to be corrected. Senjur (2012) argued that the success of the Eurozone's small middle-income members is questionable. Holtemöller and Zeddies (2013) demonstrated that the euro has not affected international price competition. Alessandrini et al. (2014) discussed the financial fragility of the Eurozone caused by external imbalances. Zestos et al. (2016) examined the causality between trade surpluses and public debt in the Eurozone. Gyoerk (2017) evaluated the costs and benefits of joining in the EMU. Canale et al. (2017) discussed a policy trilemma in the Eurozone regarding the trade-offs between free capital mobility, financial stability, and fiscal policy flexibility.

However, the empirical studies have not offered an empirical policy evaluation study to assess the causal effect between the euro and the growth rate of the Eurozone. This study offers an empirical analysis that adequately addresses this issue, and thus, determine whether there are growth effects for the Eurozone emerging from the introduction of the euro.

\section{Method and Experimental Design}

This study is based on the assumption that the introduction of the euro creates an environment for a natural (or quasi) experiment. A natural experiment occurs when a policy change or an event alters the environment for the subject under study. The policy change or the event could be the enactment of a law, the implementation of a program, or a shift in the economic and government 
environment. The introduction of the euro and the formation of the Eurozone constitute the policy change that created the environment for this natural experiment. This is because the economic environment for the Eurozone's member countries changed as they abandoned their own currencies and adopted the euro, creating the Eurozone, the largest monetary union worldwide.

When the data are generated from a natural experiment process, the DiD method can be applied to determine the causal effects between the policy change and the outcome. The $\mathrm{DiD}$ method requires a treatment group and a control group. In this study, the treatment group is the Eurozone. As for the control group, nine non-Eurozone countries are grouped into three categories: (i) EU economies that do not participate in the Eurozone, such as the United Kingdom (UK), Sweden, and Denmark, (ii) European economies that are not members of the EU, such as such Switzerland and Norway, noting that nonEU members cannot be in the Eurozone, and (iii) non-European economies such as the the United States, Canada, Australia, and Japan. Thus, the DiD method can be used to evaluate the Eurozone's growth rate in comparison with the growth rate of each of the nine control group economies. In this manner, it can be determined whether the introduction of the euro has brought growth effects on the Eurozone.

Note that each of the nine control group economies exhibits similar characteristics to those of the Eurozone by being upper-income and industrialized. The experimental design is rather exhaustive in terms of the type of economies that can be in the control group. To account for systematic differences between the Eurozone and the control group economies, the DiD method requires two data periods: before and after the formation of the Eurozone. As a result, the dataset is divided into four subsets: i) the subset for the control group before the formation of the Eurozone, ii) the subset for the control group after the formation of the Eurozone, iii) the subset for the Eurozone (the treatment group) before the formation of the Eurozone, and iv) the subset for the Eurozone after the formation of the Eurozone. 


\section{Model Specification}

The model specification relies on the DiD method, where the data for the Eurozone and the respective control group economy are pooled together. Following Meyer (1995) and Woolridge (2013), the model is specified as

$$
\% \Delta Y_{i, t}=\beta_{0}+\delta_{0} D 2+\beta_{1} D E+\delta_{1} D 2 \cdot D E+\varepsilon_{i, t}
$$

where $i=E, C$. $E$ indicates the Eurozone and $C$ indicates a control group economy. Subscript $t$ indicates the data period. As a result, $\% \Delta Y_{i, t}$ indicates the growth rate of group $i$ at time $t$ measured by the growth rate of the gross domestic product (GDP). When $i=E, \% Y_{E, t}$ represents the growth rate of the Eurozone at time $t$. When $i=C, \% Y_{C, t}$ represents the growth rate of the control group economy at time $t . \beta_{0}$ represents the intercept or constant term. $D 2$ is a time dummy variable, which takes the values of zero and one for the period before and after the formation of the Eurozone, respectively.

$D E$ is a treatment dummy variable, which takes the values of zero and one for observations in the control group and in the Eurozone, respectively. $D 2 \cdot D E$ is an interaction dummy variable for the observations being in the Eurozone after the formation of the Eurozone, and $\varepsilon_{i, t}$ is the error term. The relations between the variables can be expressed as follows:

$$
\begin{aligned}
& \mathrm{E}\left[\% \Delta Y_{i, t} \mid \text { Eurozone, after }\right]=\beta_{0}+\delta_{0}+\beta_{1}+\delta_{1}, \\
& \mathrm{E}\left[\% \Delta Y_{i, t} \mid \text { Eurozone, before }\right]=\beta_{0}+\beta_{1}, \\
& \mathrm{E}\left[\% \Delta Y_{i, t} \mid \text { control, after }\right]=\beta_{0}+\delta_{0}, \\
& \mathrm{E}\left[\% \Delta Y_{i, t} \mid \text { control, before }\right]=\beta_{0} .
\end{aligned}
$$

Thus, the intercept $\beta_{0}$ denotes the expected impact on $Y_{i, t}$ (average growth rate) for a control group economy prior to the formation of the Eurozone. Coefficient $\delta_{0}$ captures the expected average difference in the growth rate of a control group economy from before to after the formation of the Eurozone. 
Thus, $\delta_{0}$ estimates the impact of time on a control group economy. The coefficient for the treatment dummy $\beta_{l}$ reflects the average difference in growth rate between the Eurozone and a control group economy prior to the formation of the Eurozone. Thus, $\beta_{1}$ measures the effect not attributed to the introduction of the euro. The coefficient of the interaction term $\delta_{l}$ is the DiD coefficient and the coefficient of interest for this study as it measures the causal effect of the formation of the Eurozone. This is because the DiD coefficient results from the difference between $\left\{\mathrm{E}\left[\% \Delta Y_{i, t} \mid\right.\right.$ Eurozone, after $]-\mathrm{E}\left[\% \Delta Y_{i, t} \mid\right.$ Eurozone, before $\left.]\right\}$ and that between $\left\{\mathrm{E}\left[\% \Delta Y_{i, t} \mid\right.\right.$ control, after $]-\mathrm{E}\left[\% \Delta Y_{i, t} \mid\right.$ control, before $\left.]\right\}$. The difference in the aforementioned differences (i.e., difference-in-differences) produces $\left\{\left(\beta_{0}+\delta_{0}+\beta_{1}+\delta_{1}\right)-\left(\beta_{0}+\beta_{1}\right)\right\}-\left\{\left(\beta_{0}+\delta_{0}\right)-\beta_{0}\right\}=\delta_{1}$. Thus, coefficient $\delta_{1}$ accounts for the average difference in growth rate between the Eurozone and a control group economy from before to after the formation of the Eurozone. As a result, $\delta_{1}$ reveals whether the expected average difference in growth rate from before to after is different between the two groups.

For the DiD procedure to produce unbiased and efficient estimates, the parallel trend assumption must apply in that the growth rate of the Eurozone and that of a control group economy did not change at different rates for other reasons. In fact, a control group economy portraysthe growth rate trend of the Eurozone if the economies in the Eurozone did not switch to the euro. The question for this empirical study is whether the DiD coefficient is positive and statistically significant, which indicates that the growth rate of the Eurozone surpassed that of a control group economy, success for the euro. Note that the DiD coefficient is often referred to as the average treatment effect coefficient because it measures the impact of the "treatment" on the average outcome of $Y_{i, t}$.

Following Meyer (1995) and Woolridge (2013), model (1) can be improved by incorporating covariates representing factors that affect the behavior of the dependent variable. Incorporating covariates may increase the explanatory power of the model, but more importantly, may improve the efficiency of estimating $\delta_{l}$ by reducing the error variance. As such, covariates, consistent with the neoclassical growth model (the growth accounting equation), 
are introduced into the model. The neoclassical growth model was first developed by Solow (1956) and Swan (1956) and extended by Cass (1965) and Koopmans (1965). Yet, it was further refined with the endogenous growth theory by Romer (1990) and Aghion and Howitt (1998) and with recent developments discussed in Acemoğlu (2009). In all its versions, the neoclassical growth model postulates that the growth rate of an economy is primarily a function of the growth rates of capital, labor, and technology.

Following the neoclassical line of thought, a production function is specified as

$$
Y_{t}=A_{t} K_{t}^{\gamma} L_{t}^{\theta}
$$

where $Y_{t}$ is the GDP, $A_{t}$ is the total factor productivity (or multifactor productivity) often generalized as "technology," $K_{t}$ is the capital input and $L_{t}$ is the labor input at time $t$, and the parameters $\gamma$ and $\theta$ account, respectively, for the elasticity of capital and labor. Taking the total differential of (2) with respect to time produces

$$
\frac{d Y_{t}}{d t}=\frac{\partial Y_{t}}{\partial A_{t}} \frac{d A_{t}}{d t}+\frac{\partial Y_{t}}{\partial K_{t}} \frac{d K_{t}}{d t}+\frac{\partial Y_{t}}{\partial L_{t}} \frac{d L_{t}}{d t}
$$

Considering that

$$
\frac{d Y_{t}}{d t}=\frac{Y_{t}}{A_{t}}, \quad \frac{d Y_{t}}{d K_{t}}=\gamma \frac{Y_{t}}{K_{t}}, \quad \frac{d Y_{t}}{d L_{t}}=\theta \frac{Y_{t}}{L_{t}}
$$

(3) becomes

$$
\frac{d Y_{t}}{d t}=\frac{Y_{t}}{A_{t}} \frac{d A_{t}}{d t}+\gamma \frac{Y_{t}}{K_{t}} \frac{d K_{t}}{d t}+\theta \frac{Y_{t}}{L_{t}} \frac{d L_{t}}{d t}
$$


Dividing both sides of (4) by $Y_{t}$ produces

$$
\frac{1}{Y_{t}} \frac{d Y_{t}}{d t}=\frac{1}{A_{t}} \frac{d A_{t}}{d t}+\gamma \frac{1}{K_{t}} \frac{d K_{t}}{d t}+\theta \frac{1}{L_{t}} \frac{d L_{t}}{d t}
$$

Considering that

$$
\frac{d Y_{t}}{d t}=\lim _{\Delta t \rightarrow 0} \frac{Y_{t+\Delta t}-Y_{t}}{\Delta t} \approx \frac{Y_{t+\Delta t}-Y_{t}}{\Delta t} \text { if } \Delta t \text { is small. }
$$

For neighboring time periods where $\Delta t=1$

$$
\frac{d Y_{t}}{d t} \approx Y_{t+1}-Y_{t}
$$

which implies

$$
\frac{1}{Y_{t}} \frac{d Y_{t}}{d t} \approx \frac{Y_{t+1}-Y_{t}}{Y_{t}}=\% \Delta Y_{t}
$$

Therefore,

$$
\frac{1}{A_{t}} \frac{d A_{t}}{d t} \approx \% \Delta A_{t}, \quad \frac{1}{K_{t}} \frac{d K_{t}}{d t} \approx \% \Delta K_{t}, \quad \frac{1}{L_{t}} \frac{d L_{t}}{d t} \approx \% \Delta L_{t},
$$

As a result, (5) becomes

$$
\% \Delta Y_{t}=\% \Delta A_{t}+\gamma\left(\% \Delta K_{t}\right)+\theta\left(\% \Delta L_{t}\right)
$$

This method allows the transition of $Y_{t}, A_{t}, K_{t}$, and $L_{t}$ from levels in (2) to respective growth rates in (6). Equation (6) is often referred to as the growth 
accounting equation, which postulates that the growth rate of an economy depends on supply-side factors such as the growth rates of total factor productivity and available capital and labor.

When the growth accounting equation in (6) is incorporated into the basic DiD model in (1), the improved model becomes

$\% \Delta Y_{i, t}=\beta_{0}+\delta_{0} D 2+\beta_{1} D E+\delta_{1} D 2 \cdot D E+\mu\left(\% \Delta A_{i, t}\right)+\gamma\left(\% \Delta K_{i, t}\right)+\theta\left(\% \Delta L_{i, t}\right)+\varepsilon_{i, t}$

where $\% \Delta A_{i, t}$ is the growth rate of total factor productivity for group $i$ at time $t$ measured by an index, $\% \Delta K_{i, t}$ is the growth rate of capital for group $i$ at time $t$ measured by the growth rate of fixed capital formation, $\% \Delta L_{i, t}$ is the growth rate of labor for group $i$ at time $t$ measured by the growth rate of total employment, and $\mu, \gamma$, and $\theta$ are regression parameters relevant to the growth accounting equation.

When $i=E, \% A_{E, t}, \% \Delta K_{C, t}$, and $\% \Delta L_{C, t}$ represent the growth rates of total factor productivity, capital, and labor, respectively, for the Eurozone at time $t$. Likewise, when $i=C, \% A_{C, t}, \% \Delta K_{C, t}$, and $\% \Delta L_{C, t}$ represent the growth rates of total factor productivity, capital, and labor for a control group economy at time $t$. In this manner, the basic DiD model has been augmented by including supply-side determinants of growth, consistent with the neoclassical theory of growth, and in particular, the growth accounting equation.

\section{Data}

The control group data for $\% \Delta Y_{C, t}, \% \Delta K_{C, t}$, and $\% \Delta L_{C, t}$ are taken from the OECD. Stat, Economic Outlook, No.100, November 2016, Annual Projections. The data for the control group $\% \Delta A_{C, t}$ and the Eurozone data for $\% \Delta Y_{E, t}, \% \Delta A_{E, t}, \% \Delta K_{E, t}$, and $\% \Delta L_{E, t}$ are taken from European Commission, Economic and Financial Affairs, AMECO (last update February 13, 2017). For the computation of $\% \Delta Y_{E, t}, \% \Delta A_{E, t}, \% \Delta K_{E, t}$, and $\% \Delta L_{E, t}$, the series "Euro 
area (12 countries)," henceforth EA12, is used, which reports data for $Y_{E, t}, A_{E, t}$, $K_{E, t}$, and $L_{E, t}$. Note that the relevant series for $A_{C, t}$ and $A_{E, t}$ is in the form of an index from which $\% \Delta A_{C, t}$ and $\% \Delta A_{E, t}$ are computed. The EA12 are the initial 11 member countries that created the Eurozone in 1999: Austria, Belgium, Germany, Spain, Finland, France, Ireland, Italy, Luxembourg, Netherlands, and Portugal, plus Greece, which joined in 2001.

All data reflect annual observations. The period of the data spans from 1980 to 2016. As a result, $t=37$ when $i=E$, and likewise, $t=37$ when $i=$ $C$. Thus, there are 37 observations for the Eurozone and as many for each control group economy. When the data are pooled together for estimation, there are 74 observations available for each pairwise comparison between the Eurozone and each of the nine control group economies. Exceptions are the cases of Switzerland, Canada, and Australia, where the dataset comprises 62, 72 , and 73 observations, respectively, due to missing data. The period from 1980 to 1998 indicates the period prior to the formation of the Eurozone, whereas that from 1999 to 2016 indicates the period after the formation of the Eurozone. Therefore, the four data subsets required for the DiD method include i) the control group subset before the formation of the Eurozone from 1980 to 1998 , ii) the control group subset after the formation of the Eurozone from 1999 to 2016, iii) the Eurozone subset before the formation of the Eurozone from 1980 to 1998, and iv) the Eurozone subset after the Eurozone was formed from 1999 to 2016.

\section{Estimation and Results}

After the data for the Eurozone and the respective control group economy are pooled together, the improved model (7) is estimated using ordinary least squares. There are nine control group economies, and therefore, nine pairwise comparisons. Results for each of the nine pairwise comparisons are presented in Table 1 . The coefficient of interest is $\delta_{1}$, the $\mathrm{DiD}$ coefficient, which 
measures the effect of the policy change, that is, after the implementation of the Eurozone. The alternative (null) hypothesis is denoted as $\delta_{1}>0(\delta 1=0)$ indicating that the growth rate of the Eurozone exceeds (is no different than) that of a control group economy.

Regarding control group I, all $\delta_{1}$ coefficients are not statistically significant, and thus, the null hypothesis is not rejected. This implies that no significant difference exists between the growth rate of the Eurozone and those of the EU members but euro outsiders (the UK, Sweden, and Denmark). Thus, the evidence suggests that the euro has not propelled the Eurozone's growth rate to exceed that of the United Kingdom (UK), Sweden, and Denmark. As a result, the growth rates of the UK, Sweden, and Denmark have not been adversely affected by not adopting the euro. This finding provides additional empirical evidence to the ongoing debate of whether it would have been beneficial for the EU members but euro outsiders to adopt the euro. Studies have been discussing interesting aspects of this debate, such as Huhne (2001), Jonung (2002), Minford (2004), Minford et al. (2004), Vaubel, R. (2004), Jonung and Vlachos (2007), Pesaran et al. (2007), Buiter (2008), Flam et al. (2008), Soderstrom, (2008), Reade and Volz (2009), and Bryant and Joyeux (2010).

As for the economies under control group II, the respective DiD coefficients show that the growth rate of the Eurozone is significantly lower than that of Switzerland by $0.4396 \%$ but not significantly different from that of Norway. This result implies that Switzerland has been benefited substantially by not being a Eurozone member. In addition, Norway has not been adversely affected by not being part of the Eurozone. With respect to control group III, the DID coefficient for the United States, shows no significant difference in growth rate between the Eurozone and the United States. However, Eurozone's growth rate is significantly lower than that of Canada and Australia by $0.3990 \%$ and $0.5631 \%$, respectively. Finally, the DiD coefficient for Japan shows that Eurozone's growth rate is significantly higher than that of Japan by $0.9013 \%$. 


\begin{tabular}{|c|c|c|c|c|c|}
\hline \multirow{4}{*}{ 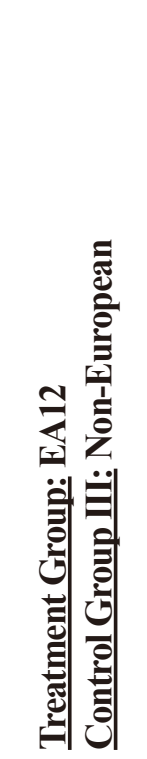 } & 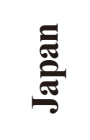 & 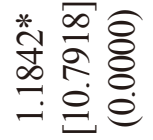 & 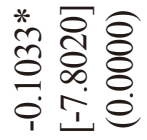 & 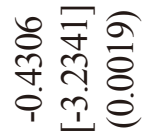 & 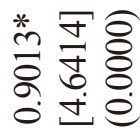 \\
\hline & 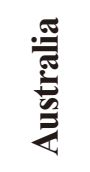 & 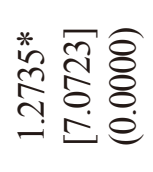 & 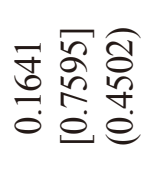 & 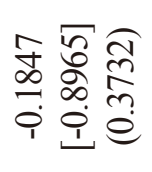 & 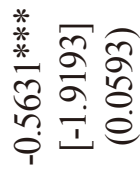 \\
\hline & نั & 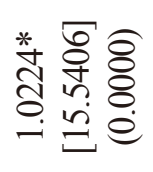 & 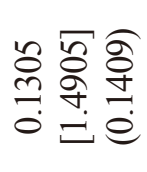 & 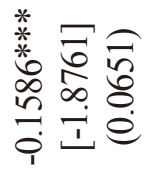 & 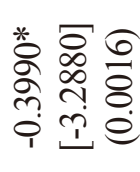 \\
\hline & 总总 & 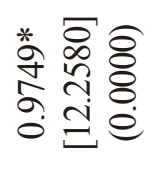 & 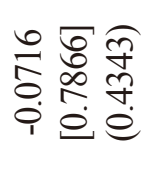 & 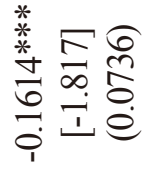 & 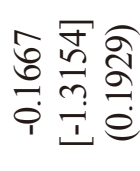 \\
\hline \multirow{2}{*}{ 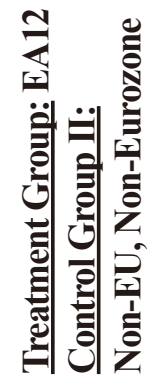 } & 产 & 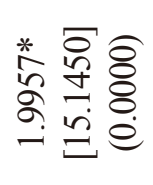 & 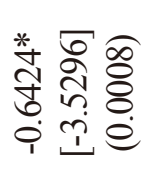 & 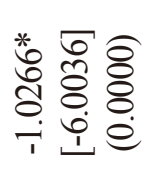 & 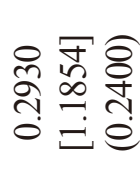 \\
\hline & & 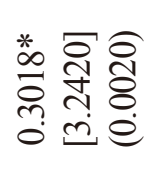 & 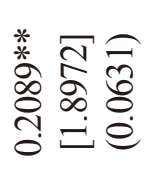 & 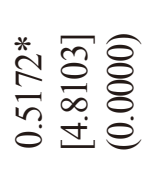 & 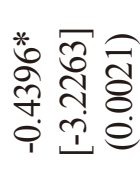 \\
\hline \multirow{3}{*}{ 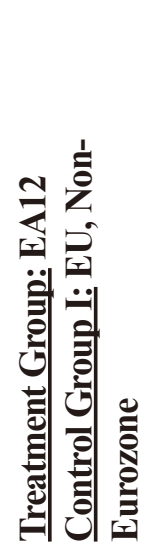 } & 里 & 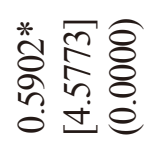 & 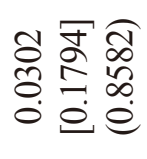 & 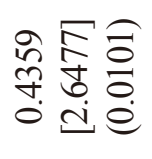 & 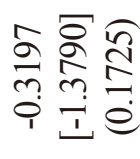 \\
\hline & हैं & 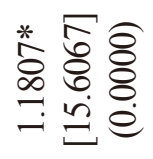 & 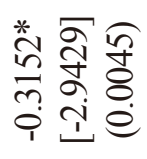 & 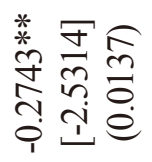 & 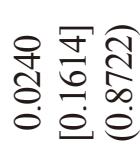 \\
\hline & 总言总 & 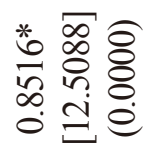 & 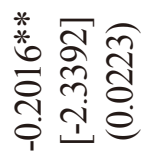 & 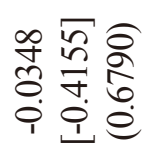 & 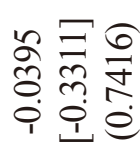 \\
\hline & & 2 & $10^{\circ}$ & $a^{2}$ & $\infty^{-}$ \\
\hline
\end{tabular}




\begin{tabular}{|c|c|c|c|c|c|c|}
\hline \multirow{4}{*}{ 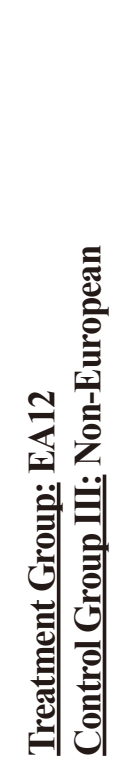 } & 䓌 & 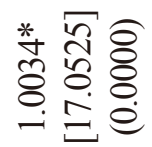 & 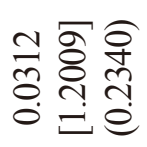 & 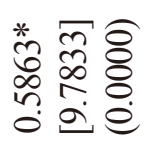 & $\frac{a}{\circ}$ & $\mathbb{Z}$ \\
\hline & 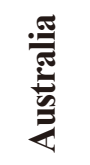 & 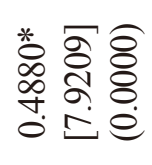 & 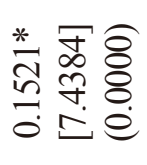 & 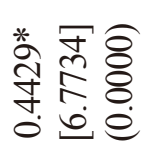 & $\begin{array}{l}\frac{1}{\infty} \\
\frac{\infty}{\infty} \\
0 \\
0\end{array}$ & $\Re$ \\
\hline & Uึ & 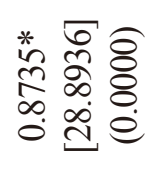 & 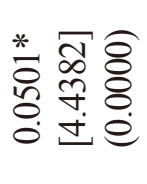 & 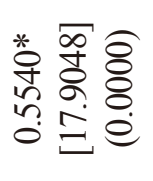 & 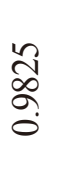 & $\mathbb{N}$ \\
\hline & 宽造 & 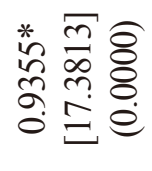 & 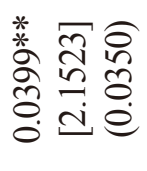 & 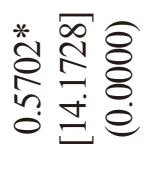 & $\frac{\partial}{\hat{\sigma}}$ & $\mathbb{t}$ \\
\hline \multirow{2}{*}{ 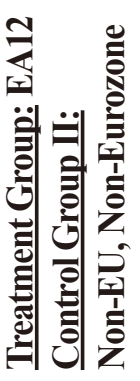 } & 己े & 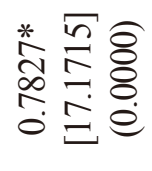 & 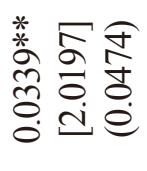 & 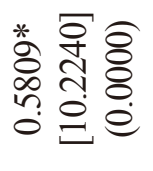 & $\frac{n}{a}$ & $\mathbb{t}$ \\
\hline & 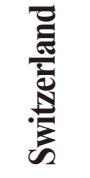 & 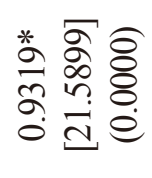 & 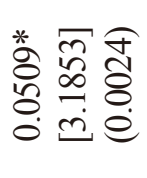 & 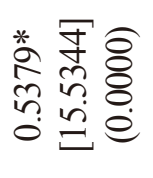 & $\begin{array}{l}\infty \\
\frac{\infty}{5} \\
\vdots \\
0\end{array}$ & $\widetilde{\sigma}$ \\
\hline \multirow{3}{*}{ 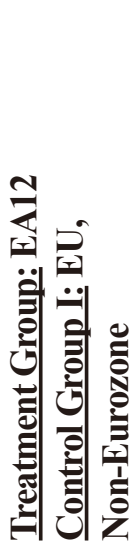 } & 范 & 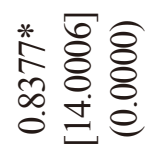 & 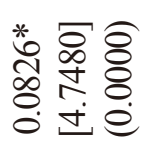 & 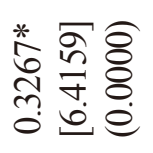 & 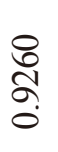 & $\mathbb{Z}$ \\
\hline & क्षे & 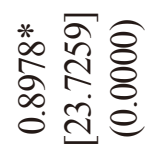 & 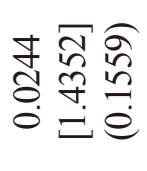 & 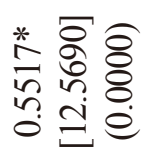 & $\frac{\stackrel{\infty}{n}}{\grave{a}}$ & $\underset{\sim}{ \pm}$ \\
\hline & 氮言 & 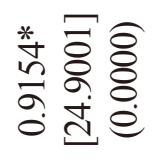 & 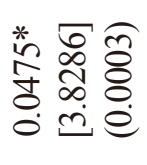 & 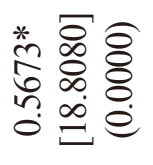 & $\begin{array}{l}\stackrel{1}{\infty} \\
\stackrel{\infty}{0}\end{array}$ & $\underset{\tau}{\mathbb{2}}$ \\
\hline & & 2 & $\gamma$ & 0 & 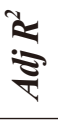 & $=$ \\
\hline
\end{tabular}


The remaining coefficients play a peripheral role and their interpretation is less consequential for the subject matter. The intercept term $\beta_{0}$, which accounts for the average growth rate of the control group economy prior to the implementation of the Eurozone, assumes a positive sign; as expected, it is statistically significant for each of the control group economies without exceptions. For example, coefficient $\beta_{0}$ for the UK. shows that the average growth rate for the UK. before the implementation of the Eurozone was a significant $0.8516 \%$ per year. Similarly, coefficient $\delta_{0}$ estimates the average change in growth rate from before to after the formation of the Eurozone within the control group, and provides mixed evidence in terms of its sign and statistical significance. This coefficient is negative and significant for the UK, Sweden, Norway, and Japan; negative but not significant for the United States; positive and significant for Switzerland; and positive but not significant for Canada and Australia. For the UK the coefficient is -0.2016 , which implies that the average growth rate of the UK. before exceeds that after the formation of the Eurozone by a statistically significant $0.2016 \%$. The remaining $\delta_{0}$ coefficients can be interpreted similarly. Coefficient $\beta_{1}$ estimates the average difference in growth rate between the Eurozone and control group economy prior to the formation of the Eurozone; it also provides mixed evidence. This coefficient is negative and statistically significant for Sweden, Norway, the United States, Canada, and Japan; negative but not significant for the UK. and Australia; positive and significant for Switzerland; and positive but not significant for Denmark. For instance, this coefficient for the UK. equals -0.0348, which implies that prior to the formation of the Eurozone, the growth rate of the UK. was higher by an insignificant $0.0348 \%$ than that of the Eurozone. The remaining $\beta_{1}$ coefficients can be interpreted similarly.

The coefficients of the growth accounting equation, $\mu, \gamma$, and $\theta$, are all positive and statistically significant across all control groups, as expected. This implies that the growth rates of total factor productivity, capital, and labor are all important determinants for growth as the theory behind the 
neoclassical growth model and the growth accounting equation postulates. The only exception is the $\gamma$ coefficients for Sweden and Japan, which are not statistically significant but still have a positive sign, as expected. The values of the adjusted $R^{2}\left(\operatorname{adj} R^{2}\right)$ and the sample size $(n)$ for each pairwise comparison are also reported.

Unit root testing is conducted to ensure the stationary nature of the variables involving growth rates. Table 2 presents the results for the Augmented Dickey-Fuller (ADF) test when an intercept and a linear trend are included in the auxiliary test regression.

The $\mathrm{p}$-values provide evidence that the null hypothesis of a unit root is rejected for each variable tested. This is to be expected as the variables tested are growth rates. The ADF test was also run with a linear trend but without an intercept as well as with an intercept but without a linear trend. Those tests produced similar results as in Table 2, and thus, are omitted for brevity. 
Table 2. ADF unit root test

\begin{tabular}{|c|c|c|}
\hline Variable & $t$-statistic & $p$-value \\
\hline EA12-UK: $\% \Delta Y_{i, \mathrm{t}}$ & -5.209828 & $0.0003 *$ \\
\hline EA12-UK: $\% \Delta A_{i, \mathrm{t}}$ & -6.027428 & $0.0000^{*}$ \\
\hline EA12-UK: $\% \Delta K_{\mathrm{i}, \mathrm{t}}$ & -6.317093 & $0.0000^{*}$ \\
\hline EA12-UK: $\% \Delta L_{i, \mathrm{t}}$ & -5.319830 & $0.0002 *$ \\
\hline EA12-SWEDEN: $\% \Delta Y_{i, \mathrm{t}}$ & -6.203949 & $0.0000 *$ \\
\hline EA12-SWEDEN: $\% A Y_{i, \mathrm{t}}$ & -6.876934 & $0.0000^{*}$ \\
\hline EA12-SWEDEN: $\% \Delta K_{i, \mathrm{t}}$ & -5.877806 & $0.0000^{*}$ \\
\hline EA12-SWEDEN: $\% \Delta L_{i, \mathrm{t}}$ & -5.452637 & $0.0000^{*}$ \\
\hline EA12-DENMARK: $\% \Delta Y_{i, \mathrm{t}}$ & -6.101384 & $0.0000 *$ \\
\hline EA12-DENMARK: $\% A Y_{i, t}$ & -6.477316 & $0.0000^{*}$ \\
\hline EA12-DENMARK: $\% \Delta K_{i, \mathrm{t}}$ & -5.471678 & $0.0001 *$ \\
\hline EA12-DENMARK: $\% \Delta L_{i, \mathrm{t}}$ & -6.465642 & $0.0000^{*}$ \\
\hline EA12-SWITZERLAND: $\% \Delta Y_{i, \mathrm{t}}$ & -6.292751 & $0.0000 *$ \\
\hline EA12-SWITZERLAND: $\% A Y_{i, \mathrm{t}}$ & -6.972242 & $0.0000 *$ \\
\hline EA12-SWITZERLAND: $\% \Delta K_{i, t}$ & -5.922964 & $0.0000^{*}$ \\
\hline EA12-SWITZERLAND: $\% \Delta L_{i, t}$ & -5.642038 & $0.0001 *$ \\
\hline EA12-NORWAY: $\% \Delta Y_{i, \mathrm{t}}$ & -5.028585 & $0.0005^{*}$ \\
\hline EA12-NORWAY: $\% A Y_{i, t}$ & -4.880926 & $0.0009^{*}$ \\
\hline EA12-NORWAY: $\% \Delta K_{i, t}$ & -5.560496 & $0.0001 *$ \\
\hline EA12-NORWAY: $\% \Delta L_{i, t}$ & -5.335177 & $0.0002 *$ \\
\hline EA12-USA: $\% \Delta Y_{i, \mathrm{t}}$ & -5.607890 & $0.0001 *$ \\
\hline EA12-USA: $\% A Y_{i, \mathrm{t}}$ & -7.001032 & $0.0000^{*}$ \\
\hline EA12-USA: $\% \Delta K_{i, t}$ & -5.043352 & $0.0000^{*}$ \\
\hline EA12-USA: $\% \Delta L_{i, t}$ & -5.720127 & $0.0003 *$ \\
\hline
\end{tabular}


(continued)

\begin{tabular}{|l|l|l|}
\hline Variable & $\boldsymbol{t}$-statistic & $\boldsymbol{p}$-value \\
\hline EA12-CANADA: $\% \Delta Y_{i, t}$ & -6.039615 & $0.0000^{*}$ \\
\hline EA12-CANADA: $\% A Y_{i, t}$ & -6.048487 & $0.000 *^{*}$ \\
\hline EA12-CANADA: $\% \Delta K_{i, t}$ & -6.265167 & $0.000 *^{*}$ \\
\hline EA12-CANADA: $\% \Delta L_{i, t}$ & -5.997518 & $0.0000^{*}$ \\
\hline EA12-AUSTRALIA: $\% \Delta Y_{i, t}$ & -5.906531 & $0.0000 *$ \\
\hline EA12-AUSTRALIA: $\% A Y_{i, t}$ & -7.966503 & $0.0000 *$ \\
\hline EA12-AUSTRALIA: $\% \Delta K_{i, t}$ & -6.344453 & $0.0000 *$ \\
\hline EA12-AUSTRALIA: $\% \Delta L_{i, t}$ & -5.832075 & $0.0000^{*}$ \\
\hline EA12-JAPAN: $\% \Delta Y_{i, t}$ & -5.699909 & $0.0001 *$ \\
\hline EA12-JAPAN: $\% A Y_{i, t}$ & -7.220581 & $0.000 *^{*}$ \\
\hline EA12-JAPAN: $\% \Delta K_{i, t}$ & -4.539234 & $0.0026^{*}$ \\
\hline EA12-JAPAN: $\% \Delta L_{i, t}$ & -5.764566 & $0.0000^{*}$ \\
\hline
\end{tabular}

(Note)The notation * indicates a statistical significance level at $1 \%$. 


\section{Conclusions}

This study conducted a policy evaluation analysis to determine whether the introduction of the euro promotes systematic growth for the Eurozone. A natural experiment and DiD methodology were used to compare Eurozone's growth with that of nine non-Eurozone economies serving as control group. The nine non-Eurozone economies exhibit similar characteristics to those of the Eurozone. The basic DiD model was augmented with supply-side covariates consistent with the neoclassical theory of growth.

It was shown that the growth rate of the Eurozone does not differ from those of the UK, Sweden, and Denmark. These three EU economies strategically decided not to adopt the euro but continued the use of their own currencies. In this case, the growth rate of these economies has not been adversely affected by not replacing their national currencies with the euro. Further, Eurozone's growth rate does not differ from that of Norway, a nonEU economy. Norway has not been adversely affected by not joining in the EU. There is also no difference between the growth rate of the Eurozone and that of the United States. In addition, the Eurozone's growth rate is significantly lower than those of Switzerland, Canada, and Australia, but exceeding that of Japan.

The evidence shows that the growth rate of the Eurozone is not signifi cantly different than that of five non-EU economies and underperforms three. The study results indicate that the euro has not been able to propel the Eurozone's growth rate to exceed those of eight out of the nine control group economies (except for Japan). It can be concluded that there are no systematic growth effects for the Eurozone emerging from the introduction of the euro. 


\section{References}

Abbott, A. J., De Vita, G. "Evidence on the impact of exchange rate regimes on bilateral FDI flows." Journal of Economic Studies, 38(3), (2011): 253274.

Acemoğlu, D. "The Neoclassical Growth Model. Introduction to Modern Economic Growth." Princeton: Princeton University Press. (2009): 287-326. ISBN 978-0-691-13292-1.

Aghion, P., Howitt, P. “Endogenous Growth Theory.” MIT Press. (1998)

Alessandrini, P., Fratianni, M., Hallett, A.H., Presbitero, A.F. "External imbalances and financial fragility in the euro area." Open Economies Review, 25, (2014): 3-34.

Baldwin, R., DiNino, V., Fontagné, L., De Santis, R. A., Taglioni, D. "Study on the impact of the euro on trade and foreign direct investment." Economic Papers 321, European Commission, Directorate-General for Economic and Financial Affairs. (2008)

Barrell, R., Gottschalk, S., Holland, D., Khoman, E., Liadze, I., Pomerant, O. "The Impact of EMU on Growth and Employment." Economic Papers 318, European Commission, Directorate-General for Economic and Financial Affairs. (2008)

Berger, H., Nitsch, V. "Zooming out: the trade effect of the euro in historical perspective." Journal of International Money and Finance, 27(8), (2008): 1244-1260.

Brouwer, J., Paap, R., Viaene, J.M. "The trade and FDI effects of EMU enlargement." Journal of International Money and Finance, 27, (2008): 188208. 
Bryant, W., Joyeux, R., "Interest linkages between the US, UK and German interest rates: should the UK join the European Monetary Union?" International Review of Applied Economics, 24(6), (2010): 633-647.

Buiter, W.H. "Why the United Kingdom should join the Eurozone." International Finance, 11(3), (2008): 269-282.

Bun, M., Klaasen, F. "The euro effect on trade is not as large as commonly thought." Oxford Bulletin of Economics and Statistics, 69, (2007): 473-496.

Canale, R.R., De Grauwe, P., Forest, P., Napolitano, O. "Is there a trade-off between free capital mobility, financial stability and fiscal policy flexibility in the EMU?" Review of World Economics, (2017): 1-25, https://doi. org/10.1007/s10290-017-0302-4.

Cass, D. "Optimum growth in an aggregative model of capital accumulation." Review of Economic Studies, 32, 3, (1965): 233-240.

Flam, H., Fatas, A., Holden, S., Jappelli, T., Mihov, I., Pagano, M., Wyplosz, C. "Should Denmark, Sweden and the UK Join?" SNS Forlag, (2008). EMU at Ten. Stockholm.

Gyoerk, E. "Economic costs and benefits of EMU membership from the perspective of a non-member." Open Economies Review, 28, (2017): 1-29.

Flassbeck, H., Spiecker, F. "The euro - a story of misunderstanding." Intereconomics, 46(4), (2011): 180-187.

Glick, R., Rose, A. "Does a currency union affect trade? The time series evidence.” European Economic Review, 46, (2002): 1125-1151.

Holtemöller, O., Zeddies, G. "Has the Euro increased international price elasticities?" Empirica, 40(1), (2013): 197-214. 
Huhne, C. "Why Britain should join the euro." European Business Journal, 13(4), (2001): 161-166.

Jonung, L. "National or international inflation targeting? The Wicksellian dilemma of the euro-outs." Journal of Public Policy, 22, (2002): 183-197.

Jonung, L., Vlachos, J. "The Euro - What's in it for Me?" An Economic Analysis of the Swedish Euro Referendum of 2003. Working Papers 296, European Commission, Brussels. (2007)

Koopmans, T.C. "On the concept of optimal economic growth." The Economic Approach to Development Planning. Chicago: Rand McNally, (1965): 225-287.

Kunroo, M.H., Sofi, I.A., Azad, N.A. "Trade implications of the Euro in EMU countries: a panel gravity analysis.” Empirica, 43(2), (2016): 391-413.

Lane, P. "The real effects of European monetary union." Journal of Economic Perspectives, 20(4), (2006): 47-66.

Meyer, B.D. "Natural and quasi-experiments in Economics." Journal of Business \& Economic Statistics, 13(2), (1995): 151-161.

Minford, P. "Britain, the euro, and the five tests." Cato Journal, 24(1/2), (2004): 75-87.

Minford, P., Meenagh, D., Webb, B. "Britain and EMU: Assessing the costs in macroeconomic variability." World Economy, 27(3), (2004): 301-358.

Mundell, R. "The Euro as a Stabilizer in the International Economic System." Kluwer Academic Publishers, NPA 440 pp. ISBN 0-7923-7755-9 (2000)

Mundell, R. "The significance of the euro in the international monetary system." American Economist 47(2), (2003): 27-39. 
Nitsch, V., Pisu, M. “Scalpel, please! Dissecting the euro's effect on trade. ETH Zurich and National Bank of Belgium."

Pesaran, M.H., Smith, L.V., Smith R.P. "What if the UK or Sweden had Joined the Euro in 1999? An Empirical Evaluation Using a Global VAR." International Journal of Finance \& Economics, 12(1), (2007): 55-87.

Petroulas, P. "The effect of euro on foreign direct investment." European Economic Review, 51, (2007): 1468-1491.

Reade, J.J., Volz, U. "Too much to lose, or more to gain? Should Sweden Join the Euro?" Economics Series Working Papers 442, Department of Economics, University of Oxford, Oxford. (2009)

Romer, P.M. "Endogenous Technological Change." Journal of Political Economy, 98(5),(2), (1990): 71-102.

Rose, A.K. "One money, one market: the effect of common currencies on trade." Economic Policy, 30, (2000): 7-45.

Rose, A.K." Currency unions and trade: the effect is large." Economic Policy, 33, (2001): 449-461.

Schiavo, S. "Common currencies and FDI flows." Oxford Economic Papers, 59(3), (2007): 536-560.

Senjur, M. "A competitive growth of a small middle-income country in the Eurozone is far to be assured." International Economics and Economic Policy, 9(3-4), (2012): 213-233.

Soderstrom, U. "Re-Evaluating Swedish Membership in EMU: Evidence from an Estimated Model.” NBER Working Papers 14519, National Bureau of Economic Research, Cambridge, Mass. (2008) 
Solow, R.M. "A contribution to the theory of economic growth." Quarterly Journal of Economics, 70(1), (1956): 65-94.

Sousa, J. De. "The Currency Union Effect on Trade is decreasing over Time." Economics Letters, 117, 3, (2012): 917-920.

Swan, T.W. "Economic growth and capital accumulation." Economic Record, 32 (2) (1956): 334-361.

Teulon, F. "EMU: The sustainability issue." International Journal of Business, 16(3), (2011): 272-288.

Vaubel, R. "A Critical Analysis of EMU and of Sweden Joining it." In: Ljungberg, J. (ed.), The Price of the Euro. Palgrave Macmillan, Houndmills and New York, (2004): 87-95.

Wickens, M. "Some unpleasant consequences of EMU." Open Economies Review, 21(3), (2010): 351-364.

Vickers, J. "Monetary Union and Economic Growth", Bank of England Quarterly Bulletin, August issue, (2000).

Wooldridge, J.M. "Introductory Econometrics, A Modern Approach", $5^{\text {th }}$ edition, South-Western, Cengage Learning (2013)

Wyplosz, C. "European Monetary Union: the dark sides of a major success." Economic Policy, 21(46), (2006): 207-261.

Zestos, G.K., Taylor, T.K., Patnode, R.D. "Causality within the Euro Area? Trade surpluses in the north versus public debt in the south." Journal of Eco nomic Integration, 31, 4, (2016): 898-931. 
